\title{
Synthesis and Characterization of Electrodeposited Zinc Oxide Nanostructures for Dye Sensitized Solar Cells - A Review
}

\author{
HO SOONMIN
}

Faculty of Science, Technology, Engineering and Mathematics, INTI International University, Putra Nilai, 71800, Negeri Sembilan, Malaysia soonmin.ho@newinti.edu.my

Received 27 October 2015 / Accepted 20 November 2015

\begin{abstract}
This review paper focuses on the preparation of zinc oxide nanostructures using electrodeposition method for dye sensitized solar cells. Electrodeposition method has been selected in this study due to many advantages if compared to other deposition techniques. During the deposition process, the nucleation rate can affect the structure and morphology of films. As results, experiment findings indicate that the nanoporous films with large surface area could be successfully produced using this method.
\end{abstract}

Keywords: Thin films, Dye sensitized solar cell, Semiconductor, Chalcogenide metal, Semiconductor

\section{Introduction}

Recently, dye sensitized solar cell is emerged as one of the most promising alternative renewable energy sources for converting light energy into electrical energy. Generally, it contained counter electrode ${ }^{1}$, redox electrolyte and dye-modified wide band semiconductor electrode such as zinc oxide ${ }^{2}$ nanostructure. $\mathrm{ZnO}$ films have been prepared by several deposition techniques including hydrothermal technique ${ }^{3-6}$, chemical bath deposition ${ }^{7-9}$, sol gel technique $^{10}$, spin coating $^{11}$, pulsed laser deposition ${ }^{12}$, spray pyrolysis ${ }^{13-16}$, thermal evaporation ${ }^{17}$, dip-coating method ${ }^{18,19}$ and radio frequency magnetron sputtering ${ }^{20}$ as reported in many literature reviews. Dye sensitized solar cell has many benefits such as low production $\operatorname{cost}^{21,22}$, simple manufacturing process, flexibility ${ }^{23}$ and high conversion efficiency ${ }^{24}$.

In this work, electrodeposition method has been selected to prepare zinc oxide thin films in dye sensitized solar cell application. The growth conditions will be analyzed, interpreted and discussed in this paper. Lastly, their performance in dye sensitized solar cells application is also reported.

Literature review

Lin et $a l .{ }^{25}$ reported the zinc oxide films with sheet like nanoporous morphology using electrodeposition technique. These films were deposited on indium tin oxide (ITO) glass 
using zinc nitrate (from $0.01 \mathrm{M}$ to $0.1 \mathrm{M}$ ) and sodium dodecyl sulfate (SDS). The FESEM micrographs indicate that $\mathrm{ZnO}$ films consisted of hexagonal columns at higher concentration of zinc nitrate from $0.05 \mathrm{M}$ to $0.1 \mathrm{M}$ in the absence of SDS solution. However, the micrographs show sheet like structures for the films prepared in the presence of SDS solution. This is attributed to the SDS is a peculiar surfactant and catalyzed the selfassembled growth of lamellar nanostructures. On the other hand, Lima et al., ${ }^{26}$ suggested that is a direct relationship between morphology and zinc precursor concentration. It has been shown that more porous could be observed as the concentration of zinc was reduced in scanning electron microscopy (SEM) analysis.

The $\mathrm{ZnO}$ films were deposited onto indium tin oxide glass by Christian et al., ${ }^{27}$. They found that short deposition time led to strong back reaction of photogenerated electrons from non-covered indium tin oxide glass to the electrolyte. They also conclude that the performance of solar cell is mainly depends on the pore size and pore geometry. For example, by increasing the pore size from $20-25 \mathrm{~nm}$ to $35-45 \mathrm{~nm}$, higher coverage of the surface of substrate could be observed, and leading to a higher open circuit voltage.

The influences of potential and time on the properties of $\mathrm{ZnO}$ films were investigated by Ahmed et al. ${ }^{28}$. In SEM investigation, they conclude that well defined shape of flower like $\mathrm{ZnO}$ morphology was prepared at the potential of $-1200 \mathrm{mV}$ versus SCE (saturated calomel electrode) for 1 hour. In addition, the UV-Visible spectrometry measurements also confirmed the good crystallinity with band gap of $3.37 \mathrm{eV}$.

$\mathrm{ZnO}$ films have been prepared using electrodeposition method onto fluorine doped $\mathrm{SnO}_{2}$ glass by Haller et al., ${ }^{29}$. The obtain films indicate tilted pores of various orientations in scanning electron microscopy studies. The x-ray diffraction (XRD) patterns display that the films is highly oriented along the c-axis of the wurtzite structure perpendicularly to the surface of substrate. Meanwhile, in optical properties investigations, these films transmit close to $80 \%$ of the incident light in the visible wavelength range.

Long $\mathrm{ZnO}$ nanowires and hierarchiral $\mathrm{ZnO}$ nanostructures were prepared by Kim et al. ${ }^{30}$. They observe that $\mathrm{ZnO}$ nanostructures indicated very good corrosion resistance in an acidic dye solution and showed higher power conversion efficiency if compared to $\mathrm{ZnO}$ nanowires. On the other hand, they also suggest that the length of the long $\mathrm{ZnO}$ nanowires increased with increasing anodization time at a constant voltage with a growth rate of 50-80 $\mu \mathrm{m}$ per hour.

$\mathrm{ZnO}$ films were prepared using electro deposition by Mozaffari et al., ${ }^{31}$. They observe that the growth mechanism of the $\mathrm{ZnO}$ films takes place in two important steps, namely nucleation and growth of nanoparticles. Their experiment results depict the formation of $\mathrm{ZnO}$ nanostructures which reaches its maximum at the deposition time of 1 hour. They also claim that at higher concentration of zinc, a large amount of $\mathrm{ZnO}$ was covered on the surface of substrate.

Zinc nitrate and polyvinylpyrrolidone were used to prepare $\mathrm{ZnO}$ films by Chen et al., ${ }^{32}$. They claim that the grain size and morphology were depending on the concentration of polyvinylpyrrolidone. In their experiment findings, $\mathrm{ZnO}$ films with grain sizes of 20-40 nm were observed in the concentration of $4 \mathrm{~g} / \mathrm{L}$. The band gap of these films was $3.3 \mathrm{eV}$ and had hexagonal wurtzite structure. Finally, the highest solar-to-electric energy conversion efficiency of $5.08 \%$ was obtained by using the electrodeposited double-layer $\mathrm{ZnO}$ films.

$\mathrm{ZnO}$ nanostructures were deposited on fluorine doped tin oxide substrate at $70{ }^{\circ} \mathrm{C}$ using electrodeposition method by Kung et al., ${ }^{33}$. The electrolytic bath contained zinc nitrate 
and sodium acetate solutions. A metal-free dye, coded as D149, was used in this research. Cell performance was measured using a light source and AM 1.5 filter. I-V curves of a dye sensitized solar cells fabricated by a $\mathrm{ZnO}$ thin films were analyzed. A conversion efficiencyof $4.65 \%$ was achieved for a dye sensitized solar cells $\left(0.2376 \mathrm{~cm}^{2}\right)$ with the photoanode, consisting of the double-layer film, under $100 \mathrm{~mW} / \mathrm{cm}^{2}$ illumination in the wavelength range of 400-800 $\mathrm{nm}$ as reported in their experiment results.

Yukako et al., ${ }^{34}$ have reported that indoline dye (D149) was applied for electrodeposited porous $\mathrm{ZnO}$ nanostructures. They claim the control of adsorption time and use of coadsorbing cholic acid was essential to achieve high efficiencies. They conclude that the use of cholic acid improved the cell performance as it prevents aggregation and reduces the amount of D149 adsorbed.

There are some disadvantages could be observed in dye sensitized solar cells. For example, the use of the liquid electrolyte, that is not very stable at varying temperatures. Furthermore, this electrolyte solution consists of volatile organic solvents and must be carefully sealed. Currently, chalcogenide metal thin film solar cells are considered as an option for large scale developments. Scientists are now actively participated in exploring various types of thin films such as binary, ternary and quaternary thin films as given below in order to achieve better performance of the solar cells.

Binary, ternary and quaternary thin films are;

Binary thin films: Zinc sulfide ${ }^{35}$, Zinc selenide ${ }^{36}$, Bismuth sulfide ${ }^{37}$, Zinc telluride ${ }^{38}$, Copper sulfide $^{39}$, Lead selenide ${ }^{40}$, Tin sulfide ${ }^{41}$, Nickel sulfide ${ }^{42}$, Manganese sulfide ${ }^{43}$, Iron sulfide $^{44}$, Indium sulfide ${ }^{45}$, Cadmium sulfide ${ }^{46}$, Cadmium telluride ${ }^{47}$, Antimony sulfide ${ }^{48}$, Cobalt sulphide $^{49}$, Cadmium selenide ${ }^{50}$, Lead sulphide ${ }^{51}$

Ternary thin films: Copper tin sulfide ${ }^{52}$, Zinc indium selenide ${ }^{53}$, Zinc cadmium sulfide ${ }^{54}$, Copper indium selenide ${ }^{55}$, Antimony copper sulfide ${ }^{56}$, Copper indium sulfide ${ }^{57}$, Nickel lead sulfide $^{58}$, Lead iron sulfide ${ }^{59}$, Gallium copper selenide ${ }^{60}$, Cadmium bismuth sulfide $^{61}$

Quaternary thin films: Copper indium aluminium selenide ${ }^{62}$, Copper zinc tin sulfide ${ }^{63}$

\section{Conclusion}

This review paper emphasizes on the electrodeposited $\mathrm{ZnO}$ nanostructures for the dyesensitized solar cells. These films were characterized by x-ray diffraction, scanning electronic microscopy, atomic force microscopy and photoluminescence. The properties of thin films were affected by the different deposition parameters as shown in experimental results.

\section{Acknowledgement}

INTI International University is gratefully acknowledged for the financial support of this work.

\section{Reference}

1. Masood H, Afshar G and Vahid J, Mater Sci Semiconductor Proces., 2013, 16(5), 1352-1359; DOI:10.1016/j.mssp.2012.11.010

2. Kim S S, Yum J H and Sung Y E, Solar Energy Materials Solar Cells, 2003, 79(4), 495-505; DOI:10.1016/S0927-0248(03)00065-5

3. Bayram K, Taylan G, Ilknur B, Merve S and Sebahattin T, Appl Surface Sci., 2014, 318, 32-36; DOI:10.1016/j.apsusc.2013.12.065

4. Rahman M Y A, Roza I, Umar A A and Salleh M M, J Alloys Compds, 2015, 648, 86-91; DOI:10.1016/j.jallcom.2015.05.283 
5. Meng Y, Lin Y, Lin Y and Yang J, J Solid State Chem., 2014, 210(1), 160-165; DOI:10.1016/j.jssc.2013.11.020

6. Lin Y, Lin Y, Wu J, Tu Y, Zhang X and Fang B, Ceram Int., 2015, 41(10), 1450114507; DOI:10.1016/j.ceramint.2015.07.089

7. Auttasit $\mathrm{T}$ and Lee M, Superlattices Microstruct., 2012, 52(5), 987-996; DOI:10.1016/j.spmi.2012.08.002

8. Prashant B, Ahmed E and Babasaheb S, Solar Energy, 2014,105, 445-454; DOI:10.1016/j.solener.2014.03.024

9. Karst N, Rey G, Doisneau B, Roussel H, Deshayes R, Consonni V, Ternon C and Bellet D, Mater Sci Engg B, 2011, 176(3), 653-659;

DOI:10.1016/j.mseb.2011.02.009

10. Pauporte T and Magne C, Thin Solid Films, 2014, 560, 20-26; DOI:10.1016/j.tsf.2013.11.121

11. Susmitha K, Kumar M N, Rajkumar G, Giribabu L and Raghavender M, Solar Energy, 2015, 118, 126-133; DOI:10.1016/j.solener.2015.03.054

12. Vijayalakshmy S and Subramanian B, Electrochimica Acta, 2014, 137, 131-137; DOI:10.1016/j.electacta.2014.05.141

13. Premaratne K, Kumara G R A, Rajapakse R M G and Karunarathne M L, $J$ Photochemistry Photobiology A: Chem., 2012, 229(1), 29-32; DOI:10.1016/j.jphotochem.2011.12.010

14. Parthiban R, Balamurugan D and Jeyaprakash B G, Mater Sci Semiconductor Processing, 2015, 31, 471-477.

15. Bedia FZ, Bedia A, Maloufi N, Aillerie M, Genty F and Benyoucef B, J Alloys Compounds, 2014, 616, 312-318; DOI:10.1016/j.jallcom.2014.07.086

16. Pankaj S and Lal B, International J Hydrogen Energy, 2012, 37(6), 4863-4870; DOI:10.1016/j.ijhydene.2011.12.064

17. Ghislain J F, Yamin F, Moussa S and Huang X, Mater Sci Semiconducting Processing, 2013, 16(3), 652-658; DOI:10.1016/j.mssp.2012.12.005

18. Dimitrios K, Elias S and Evangelos V, J Power Sources, 2012, 219, 9-15; DOI:10.1016/j.jpowsour.2012.07.034

19. Chou C S, Chou F C and Kang J Y, Powder Technol., 2012, 215-216, 38-45; DOI:10.1016/j.powtec.2011.09.003

20. Gong L, Liu Y, Gu X, Lu J, Zhang J, Ye Z, Chen Z and Li L, Mater Sci Semiconductor Processing, 2014, 26, 276-281; DOI:10.1016/j.mssp.2014.05.016

21. Suri P, Panwar M and Mehra R M, Mater Sci Poland, 2007, 25(1), 137-144.

22. Arpita J, Partha P D, Shruti A A and Devi P S, Solar Energy, 2014, 102, 143-151; DOI:10.1016/j.solener.2014.01.011

23. Hamadanian M, Ghomi JS, Hosseinpour M, Masoomi R and Jabbari V, Science Semiconductor Proces., 2014, 27, 733-739; DOI:10.1016/j.mssp.2014.08.017

24. Thomas W H, Rebecca A J, Alex B F M, Hal V R and Joseph T H, Energy Environ Sci., 2008, 1, 66-78; DOI:10.1039/B809672D

25. Lin Y, Yang J and Meng Y, Ceramics International, 2013, 39, 5049-5052; DOI:10.1016/j.ceramint.2012.11.103

26. Lima F A S, Vasconcelos I F and Cantu M, Ceramics International, 2015, 41(8), 9314-9320; DOI:10.1016/j.ceramint.2015.03.271

27. Christian D, Till V G, Bernd M S, Torsten O and Michael W, Materials, 2014, 7(4), 3291-3304; DOI:10.3390/ma7043291 
28. Ahmed NA, Hammache H, Makhloufi I, Eyraud M, Sam S, Keffous A and Gabouze N, Vacuum, 2015, 120, 100-106; DOI:10.1016/j.vacuum.2015.04.009

29. Haller S, Rousset J, Renou G and Lincot D, EPJ Photovoltaics, 2011, 2, DOI:10.1051/epjpv/2011021

30. Kim YT, Park J, Kim S, Park D and Choi J, Electrochimica Acta, 2012, 78, 417-421; DOI:10.1016/j.electacta.2012.06.022

31. Mozaffari S A, Ranjbar M, Kouhestanian E, Amoli HS and Armanmehr M H, Mater Sci Semiconductor Processing, 2015, 40, 285-292; DOI:10.1016/j.mssp.2015.06.081

32. Chen Z, Tang Y, Zhang L and Luo L, Electrochemica Acta, 2006, 51(26), 5870-5875; DOI:10.1016/j.electacta.2006.03.026

33. Kung C, Chen H, Lin C, Lai Y, Vittal R and Ho K, Progress Photovoltaics: Res Appl., 2014, 22(4), 440-451.

34. Yukako S, Wang X, Miura H, Matsui M and Yoshida T, J Photochem Photobiol A: Chem., 2010, 216(1), 1-7; DOI:10.1016/j.jphotochem.2010.08.015

35. Anuar K, Nani R and Ho S M, Int J Adv Engg Sci Technol., 2011, 7(1), 169-172.

36. Anuar K, Ho S M, Tan W T, Kelvin and Saravanan N, Eur J Appl Sci., 2011, 3(3), 75-80.

37. Ubale A U, Mater Chem Phys., 2010, 121, 555-560;

DOI:10.1016/j.matchemphys.2010.02.021

38. Skhouni O, El-Manouni A, Mollar M, Schrebler R and Mari B, Thin Solid Films, 2014, 564, 195-200; DOI:10.1016/j.tsf.2014.06.002

39. Anuar K, Ho S M, Tee W T, Lim K S and Saravanan N, Res J Appl Sci, Engg Technol., 2011, 3(6), 513-518.

40. Anuar K, Ho S M and Saravanan N, Turkish J Sci Technol., 2011, 6(1), 17-23.

41. Anuar K, Ho S M, Atan S and Haron M J, Res J Chem Environ., 2011, 15(3), 45-48.

42. Anuar K, Ho S M, Tan W T and Ngai C F, Am J Appl Sci., 2011, 8(4), 359-361; DOI:10.3844/ajassp.2011.359.361

43. Anuar K and Ho S M, Int J Chem Res., 2010, 1, 1-5.

44. Anuar K, Ho S M, Atan S and Saravanan N, Studia Universitatis Babes-Bolyai Chemia, 2010, 55(3), 5-11.

45. Asenjo B, Guilln C, Chaparro A M, Saucedo E, Bermudez V, Lincot D, Herrero J and Gutirrez M T, J Phys Chem Solids, 2010, 71(12), 1629-1633; DOI:10.1016/j.jpcs.2010.09.011

46. Caballero-Briones F, Calzadilla O, Chale-Lara F, Rejon V and Pena J L, Chalcogenide Lett., 2015, 12, 137-145.

47. Chen H M, Guo F Q and Zhang B H, J Semiconductors, 2009, 30, 053001-1-053001-4.

48. Ezema F I, Ekwealor A B C, Asogwa P U, Ugwuoke P E, Chigbo C and Osuji R U, Turkish J Phys., 2007, 31(4), 205-210.

49. Sartale S D and Lokhande C D, Indian J Pure Appl Phys., 2000, 38, 48-52.

50. Panthan H M, Sankapal B R, Desai J D and Lokhande C D, Mater Chem Phys., 2003, 78(1), 11-14; DOI:10.1016/S0254-0584(02)00198-0

51. Raniero L, Ferreira C L, Cruz L R, Pinto A L and Alves R M P, Physica B: Condensed Matter, 2001, 405(5), 1283-1286; DOI:10.1016/j.physb.2009.11.068

52. Anuar K, Zulkefly K, Atan S, Tan W T, Ho S M and Saravanan N, Indian J Engg Mater Sci., 2010, 17, 295-298.

53. Babu P, Reddy M V, Revathi N and Reddy K T R, J Nano Electronic Phys., 2011, 3, 85-91.

54. Song W C and Lee J H, J Korean Phys Soc., 2009, 54, 1660-1665.

55. Bari R H, Patil L A, Sonawane P S, Mahanubhav M D, Patil V R and Khanna P K, Mater Lett., 2007, 61(10), 2058-2061; DOI:10.1016/j.matlet.2006.08.015 
56. Ekuma C, Nnabuchi M, Nwabueze A and Owate I, Ceramic Trans., 2010, 222, 243-249.

57. Guan R, Wang X and Sun Q, J Nanomater., 2015, Article ID 579489, DOI:10.1155/2015/579489

58. Ho S M, Oriental J Chem., 2014, 30(3), 1009-1012; DOI:10.13005/ojc/300311

59. Joshi R K, Subbaraju G V, Sharma R. and Sehgal H K, Appl Surface Sci, 2004, 239(1), 1-4; DOI:10.1016/j.apsusc.2004.03.240

60. Lee H, Lee J, Hwang Y and Kim Y, Curr Appl Phys., 2014, 14(1), 18-22; DOI:10.1016/j.cap.2013.10.001

61. Mishra S S D, Saini K K, Kant C and Pal M, Mater Chem Phys., 2014, 146(3), 324329; DOI:10.1016/j.matchemphys.2014.03.031

62. Badrul M, Rachmat A W, Eun S L and Kyoo H K, J Ceramic Proces Res., 2007, 8, 252-255.

63. Lin Y, Ikeda S, Septina W, Kawasaki Y, Harada T and Matsumura M, Solar Energy Materials Solar Cells, 2014, 120, 218-225; DOI:10.1016/j.solmat.2013.09.006 